\title{
Marketing in the Green: A Description of Direct Selling and Relationship Marketing in Malaysian Jungles
}

\author{
DR. MOHAMMAD DAUD ALI \\ Department of Management Sciences, University of Haripur, \\ Khyber Pakhtunkhwa, Pakistan \\ dr.daud@uoh.edu.pk \\ DR. SYED IMAD SHAH \\ Assistant Professor Institute of Management Studies \\ University of Peshawar \\ MUHAMMAD TARIQ \\ Muhammadtariq@gmail.com
}

\begin{abstract}
This paper is a description of how marketing occurs in the forests of Malaysia, a focus made on the direct selling and relationship marketing in those jungles where marketers/sales people get access to their customers. These potential customers living in the shelter houses temporarily prepared in the jungles where the customers are employed for various assignments. An observation method for data and information gathering is acquired. Discussion/ unstructured interviews are made with the sales people and customers to understand the essence of direct selling and the relationship that the marketers have developed with the customers who live in the jungles. Also, pictures were drawn with a digital camera to reveal how the customers and the marketers relate while dealing with each other.
\end{abstract}

Keywords: Sales people; Customers; Direct Selling; Relationship Marketing

\section{Introduction}

This paper describes the direct selling in Malaysia with a focus on the direct selling in the Malaysian Jungles. The researcher of this study deemed it important to carry the study understanding the immense significance. The study is important more for the reason that similar kind of study has not been conducted going to the real world situation of direct selling and relationship marketing in Malaysian jungles. This study is viewed as to the one which will give future directions for the practitioners, policy makers and government related to the direct selling and will define the course of direct selling in Malaysian jungles in years to come.

\subsection{Research Gap}

From the review of the literature the researcher of the current study assumed that though many studies have been conducted on different aspects of direct selling in Malaysia as well as other countries but a specific study for direct selling in Malaysian jungles is missing. 


\subsection{Objectives of the Study}

- To highlight the benefits and challenges associated with direct selling in Malaysian jungles.

- To describe the direct selling trends and approaches as adopted inNegeri Sembilan Malaysia forests.

- To offer suggestions to the sellers for improving their selling approaches.

- To suggest to the policy makers (government) for improving the channels for direct selling.

\section{Literature Review}

Historically speaking, direct selling roots back tothe California Perfume in 1886 though its name changed to Avon these later on(Administration, 2008).Direct selling is a face-toto face selling wherein there are no fixed retailing sites (Peterson \&Wotruba,1996). The product and service are sold directly to the consumers on non-fixed retailing places and through the use of face-to-face way. The more detail definition was put forward by DSEF, the Direct Selling Education Foundation of America as "Direct Selling is a distributive method for consumptive product or service through personnel contact and at different commercial locations, mainly at home"(Administration, 2008). The benefit of direct selling on the customer front is that it offers convenience for many reasons like that of the explanations, demonstration, and product home delivery and on top of all, guarantees $(\mathrm{N}, 2016)$. On the other hand it offers flexibility to the practitioners and sellers to set their own schedule and hence they have the luxury of investing their time and energy accordingly.

Direct selling from an Indian perspective signifies towards the fact that goods are sold in ways other than the marts, stores, stalls or online mail orders rather than by a seller explaining the pros of the products(Analytics, 2013). India has undoubtedly done well with the direct selling due to the entrepreneurial culture, huge technology base and its global connections on one hand but largely due to the fact that it has a big middle class population in the world(Christopher, 2015). However, in China, most parts of the mainland is governed by laws where multilevel direct selling is somehow limited due to law(Yang, 2014). Sales approaches vary in various situations and conditions from some very unstructured and non-existent to a very structured approach(Frost, 2012). The relationship marketing concept relates to a strong long term relationship with customers for a lifelong value. This is based on commitment on the part of the distributors and trust on the part of the customers(Wang, 2009).

\section{Methodology}

This research follows the qualitative research. The non-participant observation method is used for the collection of primary data. For this purpose, the researchers observed the activities of the sellers in the seremban area of Negerisembilan, a province of Malaysia.

\subsection{Sample Size}

The researcher tried to visit along with the sellers and for this purpose ten sites were visited in the seremban area of Negeri Sembilan. These sites are the jungles where there are Indonesian expatriates who work for extracting fluid from rubber plants, a process called rubber-tapping. 


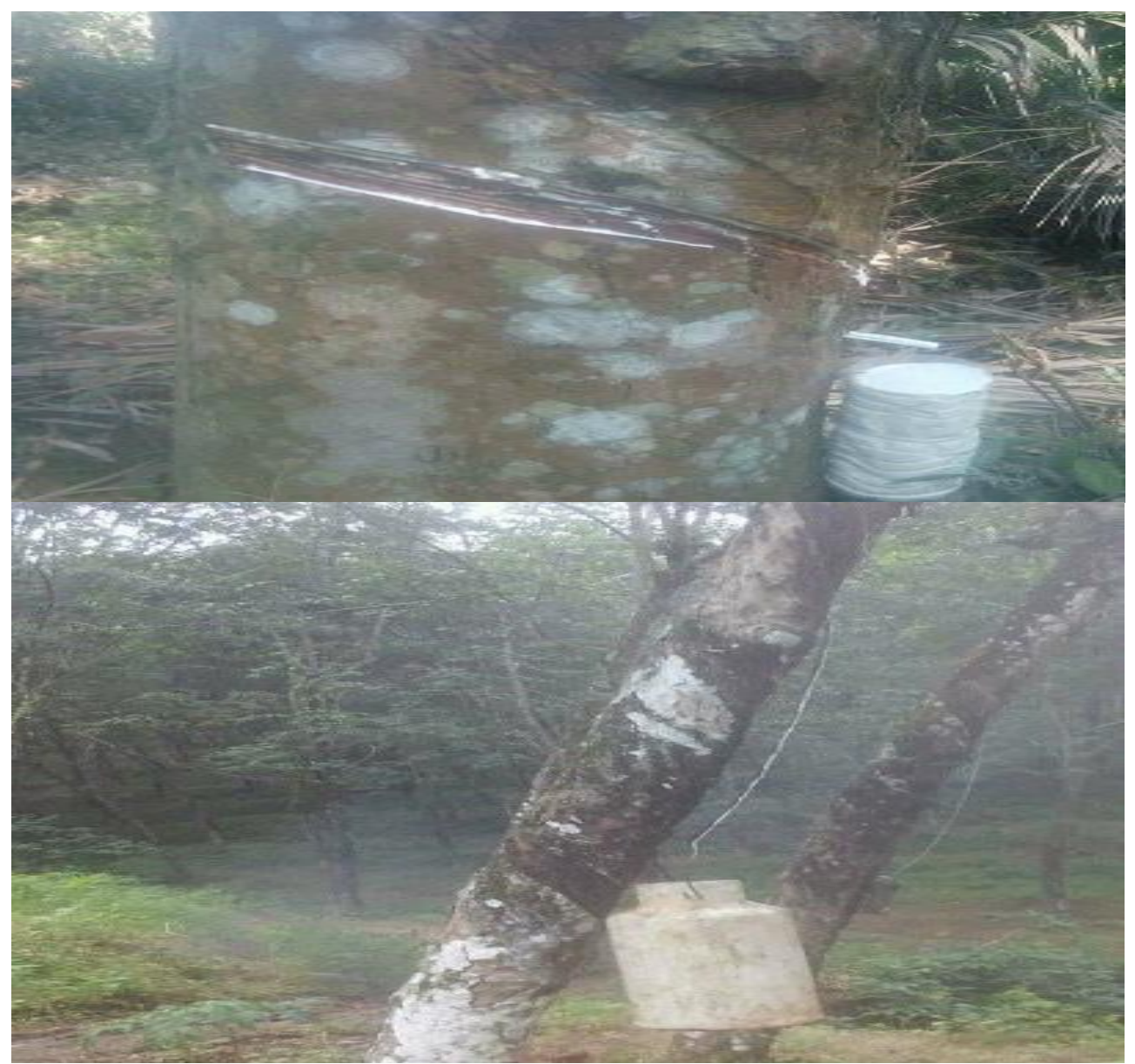

These workers live in temporary houses/shelters. The shelter houses are made of woodenrod and plastic sheets. They use anti mosquito sprays as the forests are full of insects and mosquitoes.

\subsection{Research Approach}

This is a qualitative research where the researcher has used the non-participant approach forgathering primary data by visiting the cases/respondents/subjects along with the sellers. The researchers used to watch the process of buying and selling and noted each of the steps during the process by making short notes and bullet points. The researcher also used the digital camera to draw pictures where necessary. However, the excessive use of camera was avoided fearing lest the natural flow of the buying and selling process would have been disturbed.

\subsection{Observations and Analysis}

The researcher found it interesting the way the sellers used to communicate with their customers in a friendly way. It was also a notable fact that the sellers and buyers used to snatch products from each other, showingproximity in between them. In one of the instance, the potential buyer snatched the sunglasses from the seller jokingly and the seller also enjoyed the moment. It gave the impression of wholeheartedness between the buyer and the seller. Alongside this, the sellers have established faith in their customers 
and offer them the options of installments as well. Although these customers live in temporary houses and their jobs are not permanent either.

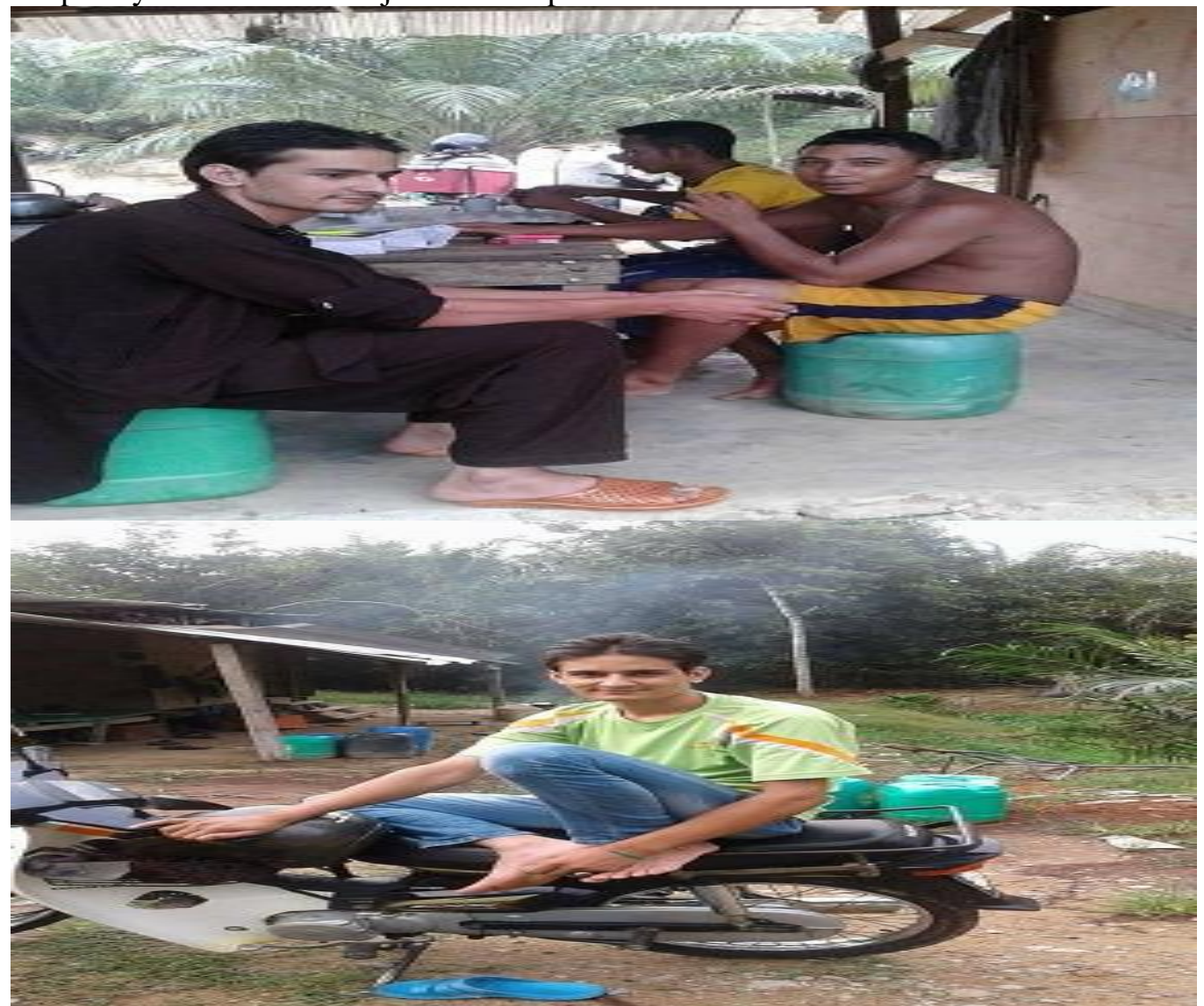

Picture 2: Husain a seller (sale person) with his potential customers in two different sites

When the researcher asked the sellers whether there is any instance when the buyers may not have kept to their words, one seller Mr. Ibrahim Syed told;

"Ours is a trade of trust. We know that these workers are not permanent here in anyway. However, we don't have many choices but to trust as these deals give us the best results. We develop good relations with our customers and resultantly they trust us more. They call us when they need some products".

This mutual trust between the sellers and buyers is evident from the fact that the sellers are just a call away from their potential customers. The customers pass on messages to the sellers for whatever goods they may need from the city centers. However, more frequently they contact the sellers for various kinds and brands of mobile/cell phones.

Another observations made by the researcher is that there is no hard feeling from the sellers even if their products are not purchased, more so even if the customers have asked them for the same. This also shows the feeling of care and relationship marketing approach on the part of the sellers. 


\section{Suggestions}

Based on the observations made by the researcher while working as a non-participant observer, recommendations are made both for the sellers as well as the policy makers and government agencies.

\subsection{Suggestions to the sellers}

I. The sellers should make their selling process more innovative by making their Products list readily available to the customers through some mobile apps.

II. Although direct selling is a time flexi business for sales people but for customers, it is not always a well known practice. This can some time create doubts in mind of the buyers. Therefore, it is highly likely that the sellers improve the trust level of potential buyers and demonstrate their merchandise more skillfully as well as honestly.

III. There can be times where the sale deals may not be successfully closed. In such particular cases the sellers need to keep themselves motivated and consistent.

IV. Most often the people are afraid of the failures and hence they do not start their careers in direct selling. To cope with this risk factor, the people who aim at this career need to take trainings to perfect the skills of direct selling.

\subsection{Suggestion to the policy makers}

I.The policy makers need to make regulatory policies not only to monitor the direct selling professional but to also facilitate them. In some cases due to lack of proper regulations, the law enforcement authorities cause inconvenience to the sellers and curtail their movement.

II. The government needs to construct proper stairs or routes to places where the forest workers are deployed. This will not only help these workers easy passages but will also minimize the risks of accidents for the sellers who face the challenge of passing though the muddy challenging terrains.

\section{References}

Administration, B. (2008). The study of direct selling management strategies: An example of the Avon cosmetics company in Taiwan, (February).

Analytics, I. (2013). Report on direct selling industry in India direct selling in India: Appropriate regulation is the key.

Christopher, M. J. B. K. J. (2015). A study on direct selling business (Amway India

Ltd) in Kerala: A case study of Calicut district ofKerala, 1489-1500.

Frost, R. (2012). Research into the Door-to- Door sales industry in, (August).

N, G. S. R. (2016). Direct selling and its benefits to the market place, 4(2), 57-64.

Peterson \& Wotruba,(1996). What is direct selling? definition, perspectives and research agenda. Journal of personal selling and sales management, 16(4), 1-16

Wang, J. (2009). Trust and relationship commitment between direct selling distributors and customers, 3(12), 862-870.

Yang, X. (2014). A review of research progress on direct selling in China Mainland and Taiwan. 